\title{
Az Európai Újraélesztési Társaság (ERC) 2021. évi újszuilött élesztés és az adaptáció támogatása ajánlásának összefoglaló bemutatása
}

\author{
Pandur Attila, Schiszler Bence, Tóth Balázs, \\ Pécsi Tudományegyetem Egészségtudományi Kar, Sürgősségi Ellátási és Egészségpedagógiai Intézet, Oxyológiai, \\ Sürgősségi Ellátási Tanszék, Pécsi Tudományegyetem Egészségtudományi Doktori Iskola
}

Bogár Bence, Jauch Melinda,

Pécsi Tudományegyetem Egészségtudományi Kar, Ápolás és Betegellátás Alapszak mentőtiszt szakirány

Prof. Dr. Betlehem József,

Pécsi Tudományegyetem Egészségtudományi Kar, Sürgősségi Ellátási és Egészségpedagógiai Intézet

Pandur Attila szakoktató

Kapcsolattartó szerző

Priskin Gábor, Dr. Radnai Balázs,

Pécsi Tudományegyetem Egészségtudományi Kar, Sürgősségi Ellátási és Egészségpedagógiai Intézet,

Oxyológiai, Sürgősségi Ellátási Tanszék

Jelen referátum az Európai Reszuszcitációs Társaság (ERC) és az International Liaison Committee on Resuscitation (ILCOR) által 2021-ben kiadott újszülött élesztés irányelveit foglalja össze. Terjedelmi okok miatt a referátum nem tartalmazza az egyes lépések teljes körü magyarázatát, a cél az új irányelvek rövid összefoglalása. Az újszülött élesztés guideline-ja lefedi az újszülött ellátást, érthető jól felépített algoritmus segíti az ellátókat feldolgozni és használni a mindennapi ellátásban a legfrissebb ajánlásokat. A guideline tárgyalja az újszülött resuscitatio lépéseit, az oktatás legfontosabb aspektusait, a hőmérsékletkontrollt. a köldökellátást a megszületést követően, az első állapotfelmérést, a légút, légzés és keringés támogatás lehetőségeit, a szülőkkel történő kommunikációt. Ezen irányelvek a megszületést követő percekre, órákra vonatkoznak, ugyanakkor az adaptáció lezajlását követő első néhány élethét során is alkalmazhatók.

\section{Az ajánlás bemutatása}

Az ERC 2021-es újraélesztési ajánlásának újszülött élesztési és az adaptáció támogatása címü fejezete 5 fö üzenetet tart fókuszban, melyek a következők:

- A késői köldökellátás alkalmazása-különös tekintettel a koraszülöttekre

- A célhőmérséklet orientált kezelés javasolt - szárazra törlés és stimulálás

- Légzés és keringés értékelése - Szívfrekvencia emelkedése kielégítő oxigenizációt jelez

- Egyszerű eszközös légút, légzés támogatás

- Mellkaskompresszió csak akkor indokolt, amenynyiben a lélegeztetés nem hatékony és a szívfrekvencia tartósan alacsony
Az ajánlás SARS-CoV-2 fertőzés gyanúja esetén javasolja a korábban kiadott guidelineok szerinti ellátást, valamint a helyi eljárásrendek követését.

\section{Tényezök a megszületés elött}

A legtöbb újszülött adaptációja eseménytelenül zajlik. Az újszülöttek 85\%-ban kielégítő spontán légzéssel születnek, beavatkozásra nincs szükség, 10\%-a igényel stimulálást és légút átjárhatóságának biztosítását, 5\%-a pozitív nyomású lélegeztetésre szorul. Mindösszesen 0,4-2\%-a szorul intubációra, 0,3\%-nál kell mellkaskompressziót végezni, és 0,05\%-ban adrenalint adni. 
Prenatális rizikótényezők felmérése és beazonosítása esetén készüljünk fel az újszülött ellátására. Lehetőségek szerint biztosítsuk a megfelelő számú és képzettségü ellátót az alábbiak szerint:

- legalább egy személy, aki képes az újraélesztést végezni

- legalább egy személy, aki kompetens az újszülöttellátásban

- egy reszuszcitációs csapat riasztható legyen, akik jártasak és megfelelő eszközökkel vannak felszerelve az újszülött élesztés összes lépéséhez

\section{Felszerelés, környezet, oktatás}

Minden eszközt rendszeresen ellenőrizzünk, lehetőség szerint csekklisták alkalmazásával. Monitor és lélegeztetéshez szükséges eszközök azonnali elérhetőségének biztosítása fontos. Újszülött reszuszcitációra jól megvilágított, huzatmentes, meleg helyen, sugárzó hőforrás alatt kerüljön sor. Intézeten kívüli ellátás során a helyi adottságoknak megfelelően jelöljük ki az újszülött ellátás helyét és minimum felszerelésként álljon rendelkezésre megfelelő védőfelszerelés (pl. gumikesztyü), fonendószkóp, hővédelem biztosításához eszközök, légzés asszisztálásához ballon-szelep-maszk, köldökellátáshoz steril eszközök. Az újszülött ellátásban résztvevő egészségügyi szakemberek folyamatos elméleti és gyakorlati ismereteit szinten kell tartani az új ajánlásokra alapozva, helyi sajátosságoknak megfelelően évente legalább egy alkalommal szimulációs oktatás, gyakorlati skillek, esetmegbeszélések, szubjektív és objektív debriefing szervezésével.

\section{Célhőmérséklet orientált kezelés}

A testhőmérséklet folyamatos monitorozása elengedhetetlen az újszülött reszuszcitáció során. Az újszülött ajánlott testhőmérséklete $36,5^{\circ} \mathrm{C}-37,5^{\circ} \mathrm{C}$. Kerüljük a hypotermiát $\left(36^{\circ} \mathrm{C}\right.$ alatt $)$ és a hypertermiát $\left(38^{\circ} \mathrm{C}\right.$ felett). Az érett újszülöttek számára $23-25^{\circ} \mathrm{C}$, a koraszülötteknek legalább $26^{\circ} \mathrm{C}$ környezeti hőmérséklet ajánlott.

\section{2. hét után született újszülöttek esetén}

A megszületést követően töröljük szárazra, majd takarjuk be a fejét és a testét, megakadályozva a lehüléstől. Amennyiben reszuszcitációra nincs szükség mielőbbi anya-újszülött bör-bőr testkontaktust teremtsünk meg. Reszuszcitáció esetén helyezzük az újszülöttet sugárzó fényforrás alá és kezdjük az élesztést.

\section{2. hét elött született újszülöttek esetén}

32. hét előtti vagy kis súlyú koraszülöttek első ellátásánál szükség lehet átlátszó műanyag zacskóra vagy fóliára, egy megfelelő méretű sapkára, esetleg melegítőmatracra, valamint emeljük a szoba hőmérsékletetét. Gondoskodjunk a lélegeztető gázok (sűrített levegő, oxigén) melegítéséről és párásításáról is. Bőr-bőr kontaktus alkalmazása esetén ügyeljünk a lehűlés elleni védelemre.

\section{Köldökellátás a megszületést követően}

Biztosítsunk elegendő időt a placentáris vér beáramlására, ha nincs szükség azonnali reszuszcitációra hagyjunk legalább 60 másodpercet minden spontán légző újszülöttnél a köldökellátással. Amennyiben a késői köldökellátás nem lehetséges egyéb okok miatt 28. betöltött gesztációs hét után alternatív lehetőségként felmerül a köldökzsinór „fejése” a placenta felől az újszülött irányába.

\section{Elsődleges állapotfelmérés}

Megszületést követően a köldökzsinór elvágása előtt döntsük el, hogy igényel-e segítséget az újszülött, ehhez vizsgáljuk az izomtónusát, a bőrszínét, a légzési tevékenységet és a pulzusát. Ezen gyors állapotfelmérés segít eldönteni a megszületést követő első teendőket. Az elsődleges állapotfelmérést követően fontos a pulzus és a légzésszám folyamatos újraértékelése.

\begin{tabular}{|l|l|l|}
\hline Izomtónus/börszin & \multicolumn{1}{|c|}{ Légzés } & Szivfrekvencia \\
\hline rózsaszín & $\begin{array}{l}\text { jó, eróteljes } \\
\text { sírás }\end{array}$ & $100 /$ perc feletti \\
\hline $\begin{array}{l}\text { törzs rózsás, } \\
\text { végtagok kékek }\end{array}$ & $\begin{array}{l}\text { lassú, } \\
\text { szabálytalan }\end{array}$ & $\begin{array}{l}60-100 / p e r c \\
\text { között }\end{array}$ \\
\hline kék, sápadt & nincs & $60 /$ perc alatti \\
\hline
\end{tabular}

Az elsődleges állapotfelmérés során jól légzo, jó izomtónussal, 100/perc feletti szívfrekvenciával rendelkező újszülött bőr-bőr kontaktusban az édesanyán helyezzünk el, oldalára fordítva, ezáltal biztosítva a légutak nyitva maradását, száraz textíliával betakarva, védve a lehűléstől. Az újszülött adaptációját nem zavarva folyamatosan figyeljük a légzését, bőrszínét, izomtónusát, testhőmérsékletét.

\section{Az újsziilöttélesztés menete}

Amennyiben az újszülött szívfrekvenciája az elsődleges állapotfelmérés során 100/perc alatti és/vagy a légzése 
nem kielégítő előmelegített felületen, sugárzó fényforrás alá fektetve:

- pozícionáljuk a fejét, neutrális helyzetet kialakítva a vállak alá helyezett textília segítségével, emeljük ki az állát.

- nyissuk meg a légutakat, szükség esetén leszívással. A légutak rutinszerü leszívása nem ajánlott.

- stimuláljuk szárazra törléssel, a hát kíméletes dörzsölésével vagy a talp ingerlésével. Amennyiben néhány másodpercen belül nem indul be az effektív légzés kezdjünk lélegeztetést.

\section{Légzés-lélegeztetés}

Mekóniumos magzatvízből született újszülött esetén kezdjünk reszuszcitációt, ugyanakkor bizonyítékok hiányában továbbra sem javasolt rutinszerü trachea leszívást végezni. Kezdjük meg a lélegeztetést mielőbb és korrigáljuk a hypoxiát.

A fent részletezett beavatkozások után értékeljük újra az újszülött állapotát, vizsgálva a légzését, keringését és oxigenizációját. Továbbra is apnoes, gaspoló, nem kielégítő légzéssel bíró újszülöttnél kezdjünk 5 kezdeti befúvást maszkon keresztül 2-3 mp-es belégzési idővel, magasabb nyomások alkalmazásával - érett újszülötteknél akár 30 vízcm, 32. hét elött születettek esetén 25 vízcm - annak érdekében, hogy az alveolusokat levegővel tölthessük fel. Értékeljük újra az újszülött légzését, mellkasmozgásait, szívfrekvenciáját. A guideline továbbra is az élesztés legfontosabb lépéseként a hatásos pozitív nyomású lélegeztetést említi. Folytassuk a lélegeztetést mindaddig, amíg kielégítő légzést és/ vagy 100 /perc feletti szívfrekvenciát nem észlelünk. 30 másodpercenként értékeljük újra az újszülött állapotát. Győződjünk meg arról, hogy a lélegeztetés hatásos-e!

Amennyiben a szívfrekvencia nem emelkedik és a légzés nem indul be vagy a mellkas nem mozog, ellenőrizzük le az eszközeinket, pozícionáljuk újra az újszülött fejét, váltsunk kétkezes maszk technikára, tekintsünk a szájüregbe, alkalmazzunk supraglotticus eszközöket.

Minden korrekció után ellenőrizzük újra, hogy hatásos-e a lélegeztetés.

\section{Oxigén adás, pulzoximetria}

Újszülött élesztés közben használjunk az $\mathrm{SpO}_{2}$ monitorozására pulzoximétert. Oxigénadást 5 perc elteltével titrálva alkalmazzunk, amennyiben a szívfrekvencia nem emelkedett és kielégítő légzést nem tapasztalunk.

\section{Mellkaskompresszió}

$\mathrm{Az}$ újszülött szívfrekvenciája hatásos lélegeztetés ellenére sem emelkedik 60/perc fölé, akkor kezdjünk mellkaskompressziót és lélegeztetést. A mellkaskompresszió megkezdésekor emeljünk a $\mathrm{FiO}_{2}$-t 100\%-ra. A kompresszió-lélegeztetés aránya 3:1 legyen. „Körülöleléses” technikát alkalmazzunk a mellkaskompressziók végzéséhez lehetőség szerint. 30 másodpercenként értékeljük újra az újszülött állapotát.

\section{Gyógyszerek}

Gyógyszerek bejuttatása történhet umbilikális vénán vagy intraosszeális úton keresztül. Az újszülött reszuszcitáció során nagyon ritkán szükséges gyógyszert adni, csak abban az esetben, ha a lélegeztetés és mellkaskompresszió nem eredményes.

\section{Adrenalin}

Indikált abban az esetben, amennyiben az újszülött szívfrekvenciája a hatékony lélegeztetés és mellkaskompresszió ellenére 60/perc alatti marad.

Dózisa: $10-30 \mu g / \mathrm{kg}$, vagyis $0,1-0,3 \mathrm{ml} / \mathrm{kg} \mathrm{az}$

1:10 000-es $(0,1 \mathrm{mg} / \mathrm{ml})$ oldatból.

(1000 mikrogramm/10 ml).

Elsőként köldökvénán vagy intraosszeális úton keresztül preferálandó. Intratracheális adás csak abban az esetben, ha nincs vénás kapcsolat és endotrachalis intubációra korábban már sor került. Adagja 50-100 $\mu \mathrm{g} / \mathrm{kg} 3-5$ percenként.

\section{Glükóz}

Elhúzódó újszülött élesztés esetén a hypoglycaemia elkerülésére 250 mg/ttkg 10\%-os glükóz adandó.

\section{Volumenpótlás}

Igazolható vérvesztés vagy hypovolaemiás sokk jelei esetén, ha az élesztésre nem reagál az újszülött adjunk $10 \mathrm{ml} / \mathrm{ttkg}$ dózisban lassan „0” negatív vérkészítményt vagy izotóniás krisztalloid oldatot.

\section{Bikarbonát}

Az acidózis elkerülése céljából, elhúzódó élesztésre nem reagáló újszülöttnek fontoljuk meg bikarbonát lassú 
adását 1-2 $\mathrm{mmol} / \mathrm{ttkg}(2-4$ $\mathrm{ml} / \mathrm{ttkg} / 4,2 \%$-ból) dózisban.

\section{Naloxon}

$200 \mu \mathrm{g}$ egyszeri dózis alkalmazása javasolt apnoés újszülött reszuszcitációja közben, amennyiben információnk van anyai opioid használatról.

\section{Posztreszuszcitációs kezelés}

Élesztésre szoruló újszülöttek esetén a légzés, keringés stabilizálódását követően is nagy hangsúlyt kell fektetni a folyamatos ellenőrzésre, mert nagy a kockázata az ismételt állapotromlásnak.

Ellenőrizzük a vércukorszintet, kerüljük el a hypo-és hyperglycaemiát.

Törekedjünk a testhőmérséklet 36,5-37,5 ${ }^{\circ} \mathrm{C}$ közötti biztosítására.

Terápiás hypotermiát csak azoknál az újszülötteknél végezzünk a helyi protokolloknak megfelelően, akiknél középsúlyos-súlyos hypoxiásischaemiás encephalopathia alakult ki.

\section{Újszülött élesztés abbaha- gyása / el nem kezdése}

Nemzetközi adatok alapján 10-20 perc folyamatos, megfelelő effektívitással végzett újszülött élesztés ellenére nem észlelhető szívműködés esetén mérlegelendő a reszuszcitáció befejezése. A klinikai döntést minden esetben egyedileg kell mérlegelni minden tényezőt figyelembevételével. Fontos

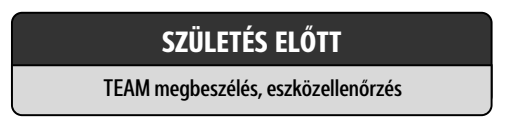

\section{KORASZÜLÖTT (<32 gesztációs hét)}

Szárazra törlés nélkül nejlonfóliába téve sugárzó hőforráshoz helyezni!
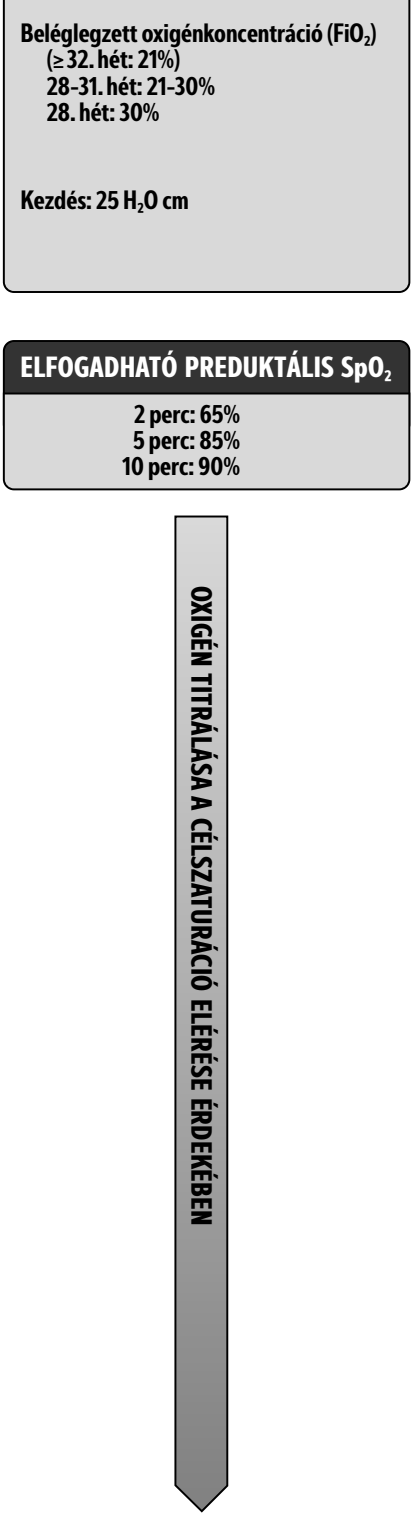

1. ábra: Az NLS algoritmusa.
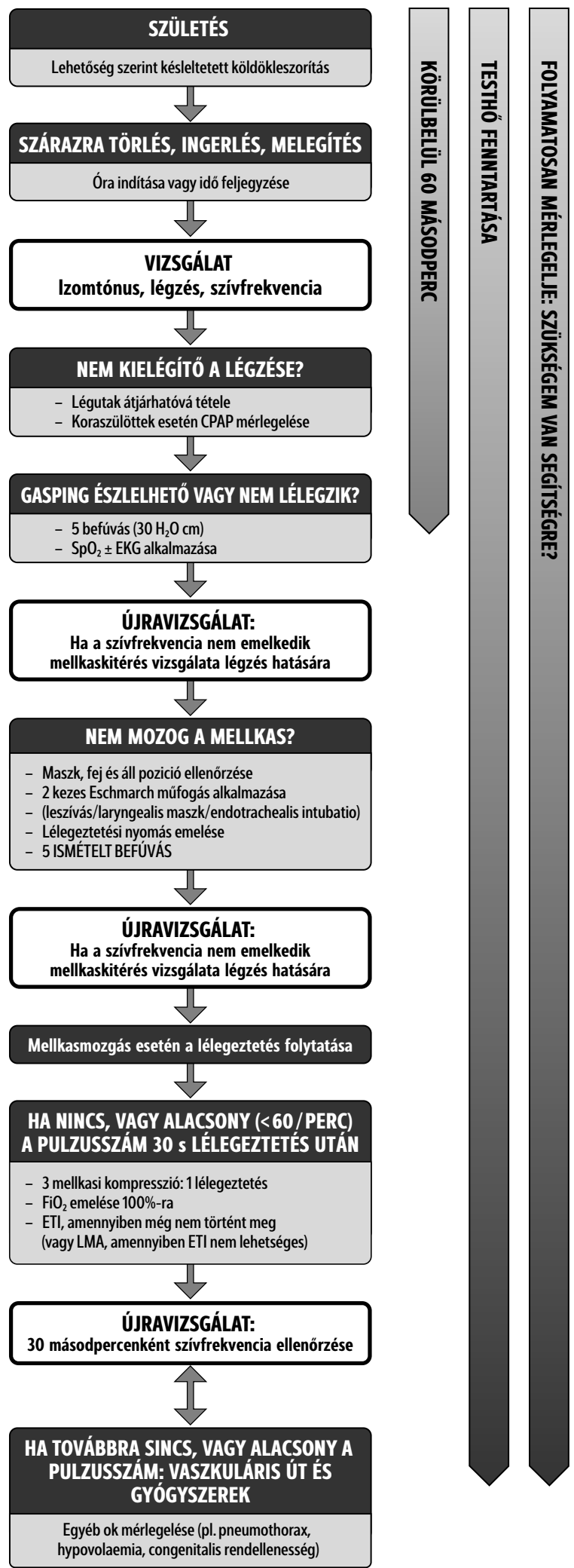

Szülök tájékoztatása, csapatmegbeszélés, dokumentáció 
a szülők felé az alapos, egyértelmű, nyílt kommunikáció alkalmazása.

Szakirodalmi adatok alapján, amennyiben életjelenséget nem mutat a 22. hét elötti gesztációs kor és/vagy a születési súly 350 gramm alatti koraszülött esetén olyan éretlenség áll fenn, amely miatt rossz életminőség, neurológiai kimenetel és várható magas halálozási adatok miatt mérlegelhető az újszülött élesztés meg nem kezdése.

\section{Változások a (pato)fiziológiai folyamatok értelmezésében, az új evidenciák tükrében}

A megszületés nagy fiziológiai változással jár a magzati állapotból újszülötté válás során, amelyek közé az alveolusok megnyílása, valamint a gázcsere megindulása nélkülözhetetlen a megfelelő kardiopulmonáris adaptációhoz. Szerencsére kevés újszülött esetén kell ezen adaptációt eszközösen támogatnunk. (1) A rizikótényezők beazonosítása a megszületés előtt segít az újszülött reszuszcitációra való felkészülésre. (2) Elektíven végzett császármetszéssel született újszülöttek esetén sem szükséges a reszuszcitáció során intubációt végezni a lélegeztetés effektivitása érdekében. (3) A jól felkészült teamek elengedhetetlenek a komplex reszuszcitáció összehangolt menedzselésében, valamint a megfelelő felszerelés csekklistákkal támogatott ellenőrzése is tovább javíthatja a sikeres élesztést. (4)(5) Ezen túlmenően a rendszeres helyi adottságokra igazított oktatás az ellátó team összeszokottságát, a skillek gyakorlása a beavatkozások sikerességét növelheti. (6)(7) Újszülött élesztést követő teamen belüli debriefing, javíthatja az ellátás minőségét. (8)(9)(10) A megszületés utáni első teendők között nagy hangsúlyt kell fektetni a hőmérséklet kontrollra. A nem megfelelő hővédelem és ezáltal a lehülés erős prediktora a halálozásnak. (11)(12) Tovább javíthatjuk az adaptációt, valamint csökkenthetjük az újszülött élesztések számát, azáltal, ha a köldökzsinór leszorítását késleltetjük, biztosítva a vitális értékek stabilizálódását a megszületést követően. (13) (14) A késői köldökellátás kontraindikált anyai vérzés, placenta abrupció, vasa praevia esetén. A köldökzsinór "fejése” alternatíva lehet ezen esetekben. (15) Az első állapotfelmérés során korábban alkalmazott APGAR osztályozás nem jelzi megfelelően az élesztésre szoruló újszülötteket, ugyanakkor egyes elemeinek gyors felmérése (légzésszám, szívfrekvencia, izomtónus) jobb prediktor. (16) A tactilis ingerek széles spektruma ismert, azonban a leghatékonyabb még módszert eddig nem sikerült azonosítani, ugyanakkor bármelyik alkalmazása növeli a 24 órás túlélését az újszülötteknek. (17) Az állapotfelmérés során az oxigénszaturáció monitorozása megbízhatóbb, mint a bőrszín által történő becslése a hypoxiának. További fontos jel az erőteljes sírás, amely a kielégítő légzéssel mutat szoros kapcsolatot. A reszuszcitáció során a pulzus megítélésére a legmegfelelőbb technika a szív feletti hallgatózás, szemben a tapintással és eszközös monitorozással. (18) Az újszülöttek esetén is a légút átjárhatóságának biztosítása az egyik alappillére az élesztés menedzsmentben. A fej neutrális pozíciójának kialakítása ajánlott az átjárhatóság biztosításának érdekében. Mind az oropharyngeális, mind a nasopharyngeális légúti szívás rutinszerủ alkalmazása késleltetheti a hypoxiás időt és lélegeztetés megkezdését. (19) Meconiumos újszülöttek esetén a légúti szívás, intubáció elmaradása nem növeli a mortalitási mutatókat, ugyanakkor ezen beavatkozás miatt késleltetett lélegeztetés elmaradása összefüggést mutat a halálozással. (20) A ventiláció során a fiziológiás légzésszámhoz korrigált lélegeztetés frekvencia biztosítja a megfelelő oxigenizációt, elősegíti a légzés megindulását a hypocapnia kialakulása nélkül. A lélegeztetés során alkalmazott 2 kézzel rögzített maszk csökkenti a levegő elszivárgását. Alternatív lehetőségként felmerül a laryngeális maszk használata, amennyiben a ballon-szelep-maszkos lélegeztetés nem effektív. (21) Az intubáció helyett nagyobb sikerességi arány biztosítható videolaringoszkóp alkalmazásával. (22) Reszuszcitáció során ritkán kell gyógyszeresen beavatkozni. A bradycardia leggyakoribb oka a hypoxia, amely az effektív lélegeztetéssel javítható. Az alkalmazott gyógyszerek hatékonyságára alacsony evidenciaszintű vizsgálatok állnak rendelkezésre az újszülött populációban. (23) Reszuszcitáció közben a szülő jelenléte segít feldolgozni sikertelenség esetén a veszteséget, az ellátás közbeni kommunikáció nélkülözhetetlen. (24) 


\section{Változások a korábbi ajánláshoz képest}

A korábbi, 2015-ben kiadott guidelineban megfogalmazott alappillérek a jelenlegi 2021-es ajánlásban sem változtak. A változásokat a következőkben foglaljuk össze.

\section{Köldökellátás}

60 másodpercet követően szorítsuk le a köldökzsinórt. 28. betöltött gesztációs hét után alternatív lehetőségként felmerül a köldökzsinór „fejése” a placenta felől az újszülött irányába.

\section{Meconiummal szennyezett magzatvíz}

Az Ajánlás nem javasolja újszülött élesztés során a korai laryngószkópiát és légúti szívást, mert ez késleltetheti a lélegeztetést, ezáltal az aspyhxiát növeli.

\section{Laryngeális maszk használata}

Amennyiben a ballon-szelep-maszkos lélegeztetés vagy az intubáció sikertelen, alternatívaként alkalmazzunk laryngeális maszkot 34 . gesztációs hetet (2000 gramm esetén, de akár már 1500 grammnál is sikeres lehet) betöltött újszülöttek esetén.

\section{Légúti csúcsnyomás}

Amennyiben a kezdeti légúti csúcsnyomás hatására nem sikerül a tüdőt megnyitni, javasolt emelni a nyomást. 32 . gesztációs kor előtt a kezdő nyomás értéke 25 vízcm.

\section{Oxigénadása az újszülött reszuszcitáció során}

32. gesztációs kort követően az újszülött élesztés során kezdjünk körlevegővel, 21-30\% oxigénkoncentrációt

\section{Irodalomjegyzék}

1. Perlman JM, Risser R. Cardiopulmonary resuscitation in the delivery room: associated clinical events. Arch Pediatr Adolesc Med 1995;149:20-5.

2. Liljestrom L, Wikstrom AK, Agren J, Jonsson M. Antepartum risk factors for moderate to severe neonatal hypoxic ischemic encephalopathy: a Swedish national cohort study. Acta Obstet Gynecol Scand 2018;97:615-23.

3. Annibale DJ, Hulsey TC, Wagner CL, Southgate WM. Comparative neonatal morbidity of abdominal alkalmazzunk 28-31. gesztációs hét között, 30\%-t pedig 28. gesztációs hét előtt.

\section{Mellkaskompresszió}

Újszülött reszuszcitáció esetén, ha mellkaskompresszió szükséges, akkor emeljünk azonnal az oxigénkoncentrációt 100\%-ra.

\section{Gyógyszerbejutattási utak}

Elsőként választandó a köldökvéna alkalmazása, alternatívaként felmerülhet az intraosszeális kanülálás gyógyszerek és folyadékok bejuttatására.

\section{Adrenalin}

Effektív lélegeztetés és mellkaskompresszió ellenére sem emelkedő szívfrekvencia esetén az adrenalin intravénás dózisa 10-30 microgramm/ttkg, amely 3-5 percenként ismételhető.

\section{Glïkóz adása az újszülött reszuszcitáció során}

Elhúzódó újszülött élesztés közben javasolt $250 \mathrm{mg} /$ ttkg 10\%-os cukoroldat alkalmazása.

\section{Kimenetel/prognózis}

10-20 perc folyamatos, megfelelö effektívitással végzett újszülött élesztés ellenére sem észlelhető szívműködés esetén mérlegelendő a reszuszcitáció befejezése, amenynyiben a reverzibilis okok kizárásra kerültek.

and vaginal deliveries after uncomplicated pregnancies. Arch Pediatr Adolesc Med 1995;149:862 7.

4. Halamek LP, Cady RAH, Sterling MR. Using briefing, simulation and debriefing to improve human and system performance. Semin Perinatol 2019; 43:151178

5. Greif R, Bhanji F, Bigham BL, et al. Education, implementation, and teams: 2020 international consensus on cardiopulmonary resuscitation and emergency cardiovascular care science with treatment recommendations. Resuscitation 2020;156;A188-239. 
6. Thomas EJ, Taggart B, Crandell S, et al. Teaching teamwork during the Neonatal Resuscitation Program: a randomized trial. J Perinatol 2007;27:409 14

7. Thomas EJ, Williams AL, Reichman EF, et al. Team training in the neonatal resuscitation program for interns: teamwork and quality of resuscitations. Pediatrics 2010;125:539 46

8. Mduma E, Ersdal H, Svensen E, et al. Frequent brief on-site simulation training and reduction in 24-h neonatal mortality an educational intervention study. Resuscitation 2015;93:1 7,

9. Schmolzer GM, Morley CJ, Kamlin O. Enhanced monitoring during neonatal resuscitation. Semin Perinatol 2019;43:151177,

10. van Vonderen JJ, van Zanten HA, Schilleman K, et al. Cardiorespiratory monitoring during neonatal resuscitation for direct feedback and audit. Front Pediatr 20164:,

11. Javaudin F, Hamel V, Legrand A, et al. Unplanned outof-hospital birth and risk factors of adverse perinatal outcome: findings from a prospective cohort. Scand J Trauma Resusc Emerg Med 2019;27:26

12. McCall EM, Alderdice F, Halliday HL, Vohra $S$, Johnston L. Interventions to prevent hypothermia at birth in preterm and/or low birth weight infants. Cochrane Database Syst Rev 2018;2:CD004210.

13. Seidler T. Umbilical cord management at preterm birth ( $<34$ weeks): systematic review and meta-analysis. Pediatrics 2021.

14. Gomersall CD. Umbilical cord management at term and late preterm birth: a systematic review and metaanalysis. Pediatrics 2021.

15. McAdams RM, Fay E, Delaney S. Whole blood volumes associated with milking intact and cut umbilical cords in term newborns. J Perinatol 2018;38:245 50.

16. Apgar V. A proposal for a new method of evaluation of the newborn infant. Curr Res Anesth Analg 1953;32:260-7
17. Baik-Schneditz N, Urlesberger B, Schwaberger B, et al. Tactile stimulation during neonatal transition and its effect on vital parameters in neonates during neonatal transition. Acta Paediatr 2018;107:952-7

18. Kamlin CO, O'Donnell CP, Everest NJ, Davis PG, Morley CJ. Accuracy of clinical assessment of infant heart rate in the delivery room. Resuscitation 2006;71:319-21.

19. Bancalari A, Diaz V, Araneda H. Effects of pharyngeal suction on the arterial oxygen saturation and heart rate in healthy newborns delivered by elective cesarean section. J Neonatal Perinatal Med 2019;12:271-6.

20. Trevisanuto D, Strand ML, Kawakami MD, et al. Tracheal suctioning of meconium at birth for nonvigorous infants: a systematic review and meta-analysis. Resuscitation 2020;149:11726.

21. Kaufman J, Schmolzer GM, Kamlin CO, Davis PG. Mask ventilation of preterm infants in the delivery room. Arch Dis Child Fetal Neonatal Ed 2013;98:F405-10.

22. Lingappan K, Arnold JL, Fernandes CJ, Pammi M. Videolaryngoscopy versus direct laryngoscopy for tracheal intubation in neonates. Cochrane Database Syst Rev 2018;6:CD009975,

23. Antonucci R, Antonucci L, Locci C, Porcella A, Cuzzolin L. Current challenges in neonatal resuscitation: what is the role of adrenaline? Paediatr Drugs 2018;20:417 28,

24. Fulbrook P, Latour J, Albarran J, et al. The presence of family members during cardiopulmonary resuscitation: European federation of Critical Care Nursing associations, European Society of Paediatric and Neonatal Intensive Care and European Society of Cardiology Council on Cardiovascular Nursing and Allied Professions Joint Position Statement. Eur J Cardiovasc Nurs 2007;6:255 8. 